Received: 20/09/2018

\title{
English Language Teaching in Secondary Schools: An Analysis of the Implementation of Indonesian ELT 2013 Curriculum
}

\author{
Nina Sofiana \\ Islamic University of Nahdlatul Ulama Jepara, Indonesia, ninasofiana @ unisnu.ac,id

\section{Husni Mubarok} \\ Islamic University of Nahdlatul Ulama Jepara, Indonesia, husni@unisnu.ac.id

\section{Issy Yuliasri} \\ Dr. M.Pd.Semarang State University, Indonesia, issy.yuliasri@mail.unnes.ac.id
}

\begin{abstract}
The study aims to determine the extent of the implementation of the English Language Teaching 2013 Curriculum in Indonesia on aspects of planning stage, teaching and learning processes, and teaching assessments. It is a cross-sectional survey which uses quantitative and qualitative approaches. The data are gathered from questionnaire, observation, interview, and documentation. Thirty-four teachers from 12 schools of 91 secondary schools in Jepara Regency, Central Java, Indonesia are selected as the sample in this study. The results showed that the planning stage conducted by teachers was in accordance with the principles of the 2013 curriculum by taking into account the core competencies, basic competencies, graduate competency standards, materials and learning activities, the selection of learning strategies and assessment. The teaching and learning process of the 2013 curriculum in English subject was well implemented. The process was also based on the principles of applicable curriculum by promoting a scientific approach. In addition, in the assessment aspect, the teachers conducted the assessment by referring to graduate competency standards by using authentic approach that assesses the readiness, the process, and the learning outcomes of the students. This indicates that the curriculum has been applied well in schools with different national examination indexes and employment status.
\end{abstract}

Keywords: Indonesian curriculum, English subject, planning stage, teaching process, learning process, teaching assessment

Citation: Sofiana, N., Mubarok, H., \& Yuliasri, I. (2019). English Language Teaching in Secondary Schools: An Analysis of the Implementation of Indonesian ELT 2013 Curriculum. International Journal of Instruction, 12(1), 1533-1544. https://doi.org/10.29333/iji.2019.12198a 


\section{INTRODUCTION}

The national curriculum in Indonesia has experienced several changes over the years. It, of course, results in some shifts including the educational content, the learning process and the assessment (Retnawati, Hadi, \& Nugraha, 2016). Therefore, teachers, as the key actors in educating students, need to fully understand the new curriculum before implementing it and concurrently improve their capabilities (Muth'im, 2014) to evoke students a pleasant and meaningful learning environment. Teachers need to be able to be aware of the content of the curriculum, the planning stage activities, and the assessment based on the curriculum focus, as well as several standards on the curriculum syllabus (Handler, 2010). Teachers also should be trained to learn teaching skills and to get awareness about English language curriculum policy as well as its importance (Rafique, Sultan, Ahmad, \& Imran, 2018). It is necessary since the success of new curriculum implementation is determined by the teachers' readiness and optimal implementation (Rumahlatu, Huliselan, \& Takaria, 2016).

To improve the education system in Indonesia, the latest curriculum applied is 2013 curriculum (K-13) which has been implemented since July 2013. The K-13 is the change of the earlier curriculum, the KTSP (the 2006 school-level autonomy curriculum). In KTSP, each school is given freedom to design its curriculum, implement, and evaluate it using local resources, broader socio-cultural dimensions, and learners' needs. On the other hand, K-13 aims to empower Indonesians to become religious, productive, innovative, and passionate citizens. It emphasizes learning designed by teachers (the taught curriculum) and learning experience (the experienced curriculum) based on students' socio-cultural backgrounds and ability (Widodo, 2016) and is designed to meet the needs of the century (Tantra, 2013). Although Indonesian curricula have changed several times, the position of English language subject still remains as compulsory subject (Hawanti, 2014).

The K-13 has been applied in every school in Indonesia, but it is still found that many teachers have implemented it unsuccessfully (Maba, Bagus, \& Mantra, 2018). The teachers are reluctant in applying authentic learning activities because some of them do not understand well about creative and innovative teaching models and strategies (Gunawan, 2017). In addition, Maba (2017) also stated that teachers are difficult to implement it since the assessment is too complicated.

In English Language Teaching (ELT), the transformation of the national curriculum in Indonesia offers a new challenge for English teachers. They need to consider the good lesson plan, the creative and meaningful teaching and learning process, and the assessment of learning outcomes. The lesson plan is important to prepare since it explains all components of objectives, learning activities, and assessment procedures (Ediger, 2002). In ELT K-13, the lesson planning needs to reflect core and basic competencies. The core competencies which include spiritual attitudes, social attitudes, knowledge, and skills are broken down into basic competencies dealing with three aspects: affective, cognitive, and psychomotor. Then, in the teaching and learning process, the current curriculum requires teachers to use a learning cycle of scientific approach. The cycle comprises observing, questioning, exploring/experimenting, 
associating, and communicating. Lastly, in relation to the assessment procedure, the ELT K-13 put emphasis on process and product-based assessment, and still prioritizes cognitively demanding assessment in which students' capability is assessed through formal assessment (Widodo, 2016).

After 5 years' implementation, several researches had been conducted related to the ELT. In the early implementation of K-13, Intansari (2013) conducted a cross-sectional survey study to investigate teachers' personal beliefs related to ELT. The result showed that there were gaps between the mandated curriculum as stipulated by the government and the implemented curriculum at the classroom level.

Another research was conducted by (Nur \& Madkur, 2014) which aimed at providing a picture of challenges, opportunities and teachers' perception toward the implementation of K-13. Through in-depth interview to six English teachers in six pilot schools in Bogor and Lampung, it could be deduced that teachers accepted the K13, but it needed evaluation and development. In the same year, Ahmad (2014) described the policymakers' perspectives on the issues of the school curriculum reform from the School-Based Curriculum (SBC) into K-13 and English teachers' perspectives and interpretations toward the policy with special reference to ELT program at senior secondary schools in Makassar. It was found that the implementation of ELT K-13 was partial, biased and tended to be traditional from the planning to the assessing process. The constraints to successful implementation of K-13 rooted on the teachers' fixed mindset and within the implementation.

The research conducted by Chairani (2015) mentioned that in the international oriented senior high school in Yogyakarta did not implement officially the K-13. However, since the learning process focused on student-centered learning and fostered the students' autonomy, ACT (Assessment Certificate Test) curriculum and the values of the school automatically reflect the 2013 Curriculum.

In relation to the ELT, Ashar and Irmawati (2016) explained deeply the K-13 implementation of English at SMKN 1 Bantaeng. Through observation, interview and examining document, it was concluded that the lesson plans prepared were generally well arranged, and most of the components in the ELT K-13 were in accordance with the indicators set by the government. However, the implementation of English language learning process still had many shortcomings, especially in the aspect of preliminary activities, the implementation of integrated learning, the selection of sources and media, as well as in the closing activities. In addition, the implementation of English language assessment was not done well, because most of the components of the assessment were not carried out. They also found some supporting factors and obstacles in implementing the K-13 of English.

Based on the previous studies, they show the implementation of the K-13 in ELT, including some constraints faced by teachers. However, the results have not considered the employment status of teachers and school indexes of national examination. Thus, it is necessary to give overview on how the $\mathrm{K}-13$, as the national curriculum, is implemented to determine the policy related to the ELT. 


\section{Purpose of the Study}

The purpose of the study was to determine the extent of the implementation of the ELT $\mathrm{K}-13$ on aspects of teaching stage, teaching and learning processes, and teaching assessments.

\section{METHOD}

\section{Design}

The method of this study was a cross-sectional survey where the study was conducted at a specific point in time and did not look for the relationship among variables. In this study, the researchers collected the data at one point in time. This study used two kinds of research approaches; quantitative and qualitative.

\section{Population and Sample}

The population of this study was English teachers in 91 secondary schools in Jepara Regency, Central Java, Indonesia. The number of schools to be a research sample was 12 schools with the total of 34 teachers. The sample was selected by considering the employment status and indexes of national examination. From the aspect of employment status, there were 8 private teachers and 26 civil servant teachers. Based on the results of national examination indexes, it was found that there were three school categories, namely high, medium, and low.

\section{Data Collection}

The data in this study were collected through questionnaires, observation, interviews, and documentation. Closed-questionnaires were used to obtain data related to planning stage and teaching assessment in the implementation of the K-13 to English language subject. These closed-questionnaires contained several sub-variables of teaching planning, teaching and learning process, and assessment. Non-participative observation was used to describe English language teaching and learning process in classroom. Structured interviews were used to clarify the data obtained from the questionnaires. Documentation was used to obtain supporting data related to the implementation of the K-13.

Table 1

Indicators of Questionnaires

\begin{tabular}{ll}
\hline Indicators & Aspects \\
\hline Teaching planning & Annual and semester program \\
& Lesson plan \\
& Effective learning hours \\
& Effective weeks \\
& Basic competencies \\
& Time allocations for each basic competency \\
& Core competency and basic competencies analysis \\
& Learning indicators \\
& Resources and teaching materials \\
& Media selection and learning strategies \\
& Preparation of four competency assessment instruments \\
\hline Teaching and Learning Process & Opening phase \\
& Core phase \\
& Closing phase \\
\hline
\end{tabular}




\begin{tabular}{ll}
\hline Teaching Assessment & Planning of assessment \\
& Implementation of assessment \\
& Assessment report \\
\hline
\end{tabular}

In this study, content validity was used to determine the extent to which the instrument reflected the expected content. Reliability calculation used internal consistency method with Alpha Cronbach calculation. Based on the calculation of Alpha Cronbach, it was found that all research instruments, consisting of teaching planning instruments, observation instruments, and teaching assessment instruments, were reliable. The results of calculation could be seen in Table 2 .

Table 2

Calculation of Instrument Reliability

\begin{tabular}{lcll}
\hline Instrument & Alpha Coefficient & Number of statements & Note \\
\hline Instrument of teaching planning & 0.869 & 23 & Reliable \\
\hline Observation sheet & 0.849 & 33 & Reliable \\
\hline Instrument of teaching assessment & 0.795 & 14 & Reliable \\
\hline
\end{tabular}

\section{Data Analysis}

This research data were analyzed both quantitatively and qualitatively. Before being analyzed, the data from questionnaire was quantified first by using a quantitative descriptive analysis, while the data from observation, interviews and documentation were analyzed qualitatively. The results of data analysis resulted in achievement score then interpreted. The change of means and accessibility to each indicator used normsreference by using a scale of four. Data from observation, interviews, and documents were analyzed by using Miles and Hubberman's method as used by Natsir, et al., (2018).

\section{FINDINGS}

This study aimed at determining the extent of the implementation of the ELT K-13 on aspects of planning stage, teaching and learning processes, and teaching assessments. Data on the planning stage and teaching assessment of the K-13 were obtained through questionnaires, while data on teaching and learning were obtained from observations in the classroom.

\section{Curriculum Implementation in the Planning Stage}

Planning is an early stage created by teachers before implementing the learning process. This data were obtained through closed-questionnaires given to all teachers. The number of statements in the questionnaire was 23 statements that were chosen by teachers. The 34 English teachers chose the option based on the category of always (4), often (3), seldom (2), or never (1). The data obtained were analyzed descriptively to produce the highest ideal score (HS) where $23 \times 4=92$, the lowest ideal (LS) score where $23 \times 1=23$,

ideal mean $(\mathrm{Mi})$ where $\frac{1}{2}(92+23)=57,5$, and Ideal standard deviation $\frac{1}{6}(92-23)=$ 11,5. The result of questionnaire calculation could be seen in Table 4 .

Table 4

Score Obtained in the Aspect of Planning Stage

\begin{tabular}{llll}
\hline Maximal score & Minimal score & Sum & Means \\
\hline 92 & 68 & 2837 & 123,4 \\
\hline
\end{tabular}


The results obtained were then categorized by the number of scores for each item of statement into four-scale conversion by using the categories; very good, good, enough and poor as shown in Table 5.

Table 5

Result Obtained in the Aspect of Planning Stage

\begin{tabular}{llll}
\hline Score interval & Category & Lesson Planning & \\
\hline & & Teachers & Percentage \\
\hline $\mathrm{HS} \geq \mathrm{X} \geq \mathrm{Mi}+1,5 \mathrm{SDi}$ & Very good & 31 & $91,17 \%$ \\
\hline $\mathrm{Mi}+1,5 \mathrm{Sdi}>\mathrm{X} \mathrm{Mi}$ & Good & 3 & $83,3 \%$ \\
\hline $\mathrm{Mi}>\mathrm{X} \geq \mathrm{Mi}-1,5 \mathrm{SDi}$ & Enough & - & - \\
\hline $\mathrm{Mi}-1,5 \mathrm{SDi}>\mathrm{X} \geq \mathrm{LW}$ & Poor & - & - \\
\hline $\mathrm{SUM}$ & & 34 & $100 \%$ \\
\hline
\end{tabular}

Where:

Mi $(\mathrm{X})=$ Ideal mean $\frac{1}{2}(\mathrm{HS}+\mathrm{LS})$

$\mathrm{SDi}=$ Ideal standard deviation $\frac{1}{6}(\mathrm{HS}-\mathrm{LS})$

HS = Highest ideal score

LS = Lowest ideal score

The results of questionnaires given to the teacher showed that the teaching planning was categorized as very good implementation. This means that the lesson plans of English subject made by teachers in secondary school in Jepara municipality was well applied. Teachers' readiness in implementing the teaching and learning process was in accordance with the procedures in the K-13. This can be seen from the lesson plans contained in syllabus and lesson plan. The syllabus and lesson plan were operational activities planning in the learning activities prepared by English teachers to be used as a reference in carrying out learning activities. English teachers have planned well the syllabus and lesson plans based on the K-13 including core competence, basic competencies, indicators, learning objectives, materials learning, scientific learning methods, activity steps learning, learning resources, and assessment.

The teaching planning of English subjects in the K-13 in schools that had low, medium, and high indexes in the national examination was categorized as very good category, but schools with medium index in national examination got higher scores than school with low and high indexes in national examination. In addition, the application of English language learning in the K-13 that was implemented by teachers with civil servant status was in very good category shown by $90 \%$ of teachers who implemented most of aspects in the curriculum. Meanwhile, the teaching planning of teachers with private employment status could reach $92 \%$. The percentage of teachers with private employment status was higher than that of teachers with civil servant status. This happens because the civil servant teachers got the lowest average score on the elaborating core competencies into basic competencies. Furthermore, the lowest score was also obtained in the aspects of cultural diversity of students in choosing learning materials. 

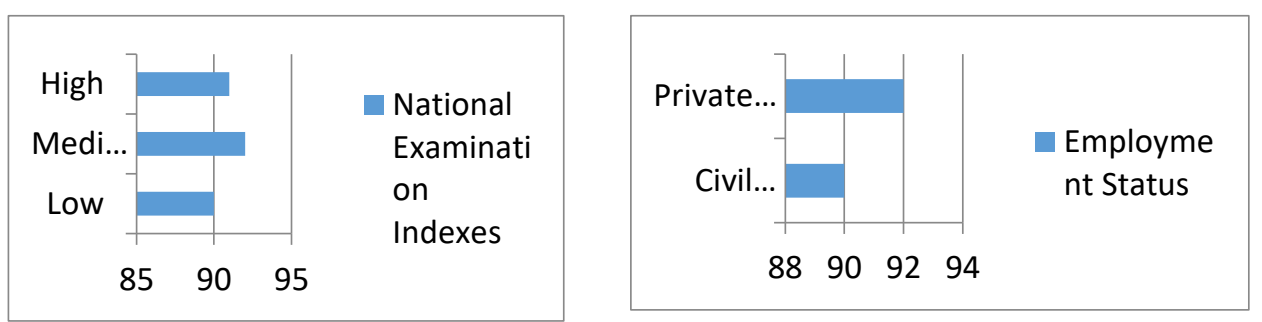

Figure 1

Teaching Planning Based on National Examination Indexes and Employment Status

\section{Curriculum Implementation in the Teaching and Learning Process}

There are three indicators of teaching and learning process namely opening, core, and closing phase. The opening phase includes preparing the students psychically and physically, explaining the learning objectives and coverage of the material, motivating the students to learn, linking the material with the student's real life and delivering a series of learning activities. The core activities include teachers' mastery of learning materials, application of learning strategies, application of scientific approaches, the use of learning resource and media in learning, authentic assessment, involvement of learners in learning, and the use of good language. The closing activities include concluding learning materials, giving feedback to learners and follow-up in the form of giving individual or group assignments and informing the upcoming learning materials.

Table 6

Score Obtained in the Aspect of Teaching and Learning Process

\begin{tabular}{llll}
\hline Score interval & Category & \multicolumn{2}{l}{ Teaching and Learning Process } \\
\hline & & Teachers & Percentage \\
\hline $\mathrm{HS} \geq \mathrm{X} \geq \mathrm{Mi}+1,5 \mathrm{SDi}$ & Very good & 3 & $33.33 \%$ \\
\hline $\mathrm{Mi}+1,5 \mathrm{Sdi}>\mathrm{X} \mathrm{Mi}$ & Good & 6 & $66.67 \%$ \\
\hline $\mathrm{Mi}>\mathrm{X} \geq \mathrm{Mi}-1,5 \mathrm{SDi}$ & Enough & - & - \\
\hline $\mathrm{Mi}-1,5 \mathrm{SDi}>\mathrm{X} \geq \mathrm{LW}$ & Poor & - & - \\
\hline $\mathrm{SUM}$ & & 9 & $100 \%$ \\
\hline
\end{tabular}

To observe the implementation of teaching and learning process, the researchers used observation sheets to observe 9 teachers from a total of 34 teachers who became research samples by using purposive sampling technique. The table above showed that English learning was very well implemented by $33.33 \%$ teachers, while it was well implemented by $66.67 \%$ teachers.

The implementation of the K-13 in English subject with low national examination index obtained $73.33 \%$ while those who did not apply it reached $26.67 \%$. Meanwhile, the implementation of the K-13 in English subjects with medium national examination index obtained a percentage of $86.67 \%$ while those who did not apply it reached $13.33 \%$. Then, the schools with the high index category in the national examination obtained $73.33 \%$ in the implementation of curriculum 2013 for English teaching and learning process and $26.67 \%$ of English teachers did not apply it in teaching and learning 
process. In conclusion, based on national examination indexes, all schools had implemented the K-13 in the teaching and learning process. However, schools with medium national exam index had high percentages compared to schools with low and high national examination indexes.

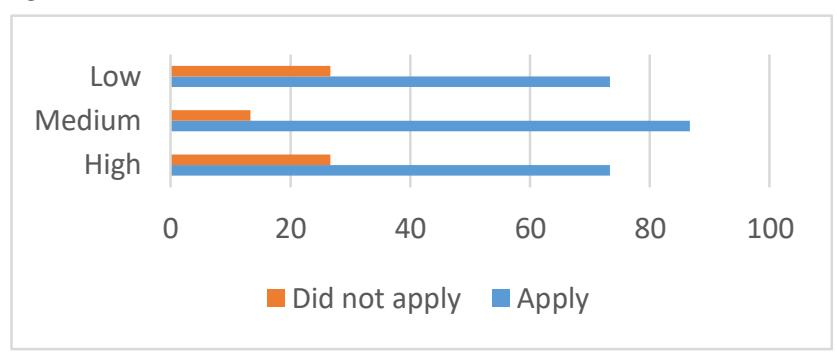

Figure 2

Teaching and Learning Process Based on National Examination Indexes

In general, the implementation of ELT in the 2013 curriculum by teachers with civil servant status was in very good category. It was shown by $77.63 \%$ of teachers who did it very well. Meanwhile, teachers with employment status as private teachers, their learning planning reached $92 \%$. The percentage of teachers with private employment status was higher than that of teachers with civil servant employment status.

The implementation of the K-13 in English subject in terms of teacher employment status were as follows: teachers with civil servant status reached $76.46 \%$ of the achievement level in the teaching and learning process, while the teaching and learning process, which was not achieved, is $23.54 \%$. Teachers with private employment status reached $70.86 \%$, while the teaching and learning process, which was not achieved, is $29.14 \%$. Although civil servant teachers and private teachers had implemented the 2013 curriculum in English subjects well, but teachers with civil servant status applied it better than private teachers.

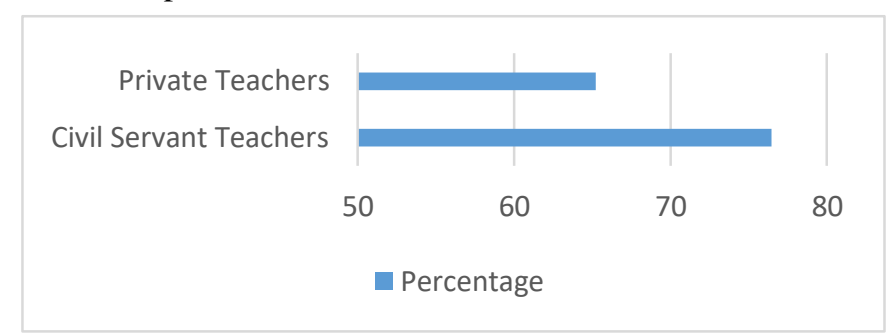

Figure 3

Teaching and Learning Process Based on Employment Status

\section{Curriculum Implementation in the Teaching Assessment}

There are three aspects of English teaching and learning assessment in the K-13, namely planning, implementation, and reporting assessment. Assessment planning indicators include the preparation of the grid and rubric of assessment instruments, the selection of 
assessment techniques, and the determination of the assessment procedure in accordance with the minimum mastery criteria. Assessment applications indicators include applying authentic assessments, daily assessments, midterm exam and final exam semester, and giving remedy for students who had not met the indicators of achievement of competence.

Table 6

Score Obtained in the Aspect of Teaching Assessment

\begin{tabular}{llll}
\hline Score interval & Category & Assessment & \\
\hline & & Teachers & Percentage \\
\hline $\mathrm{HS} \geq \mathrm{X} \geq \mathrm{Mi}+1,5 \mathrm{SDi}$ & Very good & 28 & $82.35 \%$ \\
\hline $\mathrm{Mi}+1,5 \mathrm{Sdi}>\mathrm{X} \mathrm{Mi}$ & Good & 6 & $17.65 \%$ \\
\hline $\mathrm{Mi}>\mathrm{X} \geq \mathrm{Mi}-1,5 \mathrm{SDi}$ & Enough & - & - \\
\hline $\mathrm{Mi}-1,5 \mathrm{SDi}>\mathrm{X} \geq \mathrm{LW}$ & Poor & - & - \\
\hline $\mathrm{SUM}$ & & 34 & $100 \%$ \\
\hline
\end{tabular}

The assessment implementation of the K-13 in English subject for schools with low indexes of national examination was in good category where it reached $84.34 \%$, while schools with medium indexes of national examination get $86.56 \%$. Schools with high indexes of national examination got $85.65 \%$ in the assessment implementation of 2013 curriculum. Three different schools had implemented assessment in 2013 curriculum very well, but schools with medium indexes had implemented the assessment better than schools with low and high indexes of national curriculum.

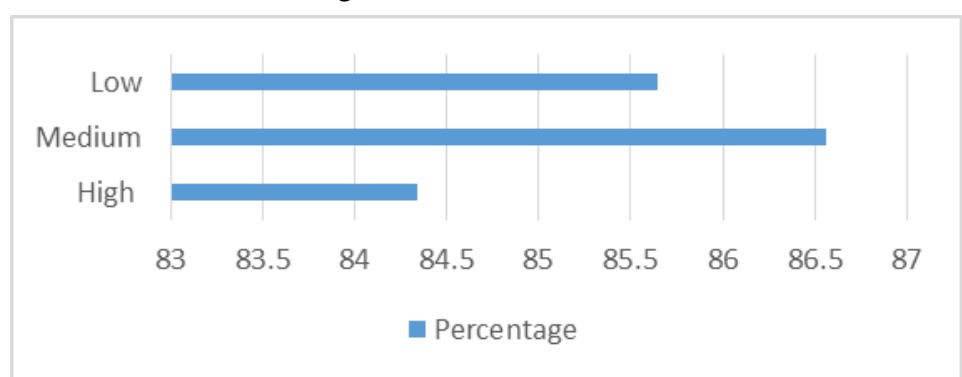

Figure 4

Teaching Assessment Based on National Examination Indexes

The implementation of the 2013 curriculum in the assessment of English learning by teachers with civil servant status obtained a percentage of $86.65 \%$ and it belonged to a very good category, while the teachers with private employment status obtained $88.45 \%$ percentage and it belonged to a very good category. Therefore, based on employment status, the teaching assessment was well implemented. However, the teachers with private employment status earned better than teachers with civil servant status. 


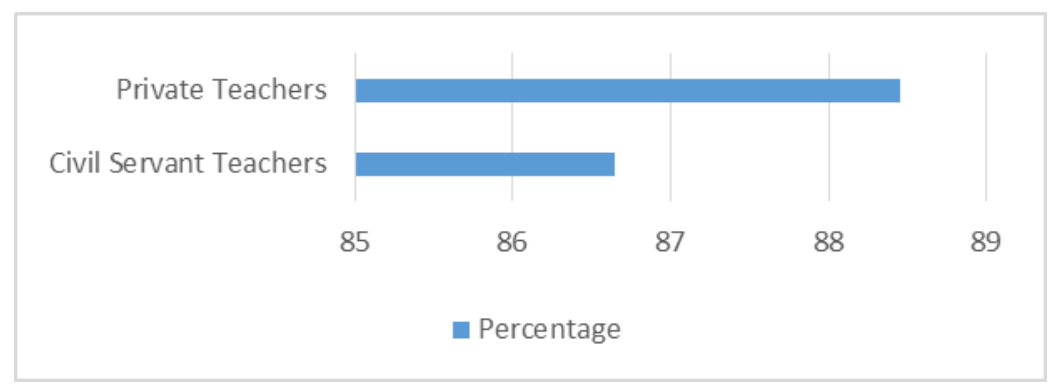

Figure 5

Teaching Assessment Based on Employment Status

\section{DISCUSSION AND CONCLUSION}

The implementation of the 2013 curriculum in English subjects on the planning aspect in Jepara district was included in the very good category. This indicates that all good teachers from different school indexes and different employment status have implemented learning plans as outlined in the 2013 curriculum. This result is also supported by the result of the 2013 curriculum document where it is found that all teachers have made annual and semiannual programs, preparing the syllabus and lesson planning. In addition, the clarification of data through interviews also indicates that before the learning begins, the teachers have prepared the learning administration. This is in accordance with Cerbin and Kopp (2006) opinion where learning planning becomes the framework required by teachers in classroom learning.

In addition, based on the result of observation, it was found that the teaching and learning process of English curriculum 2013 belonged to a very good category, especially in the three phases of learning; opening, core, and closing. At the opening phase, the teachers perform apperception and motivate the students, convey the learning objectives and explain the learning activity plan. Based on the data analysis per indicator, it indicates that the learning process done by the teacher is good but not all teachers explain the plan of learning activities in the opening phase. In the core phase, the learning done by the teacher was in the very good category. This was supported by interviews that the teachers mostly had attended the socialization and training of curriculum 2013 two times. On the other hand, English Teacher Development Group (ETDG) forum (Musyawarah Guru Mata Pelajaran or MGMP in Bahasa Indonesia) has facilitated teachers to improve their capabilities by providing them training. In the teaching and learning process, teachers also had promoted the five cycles of scientific approach. It is in line with Widodo (2016) where ELT K-13 teachers need to apply scientific approach which includes observing in-class teaching, questioning, exploring/experimenting new materials, associating to new knowledge, and communicating to other students. The closing phase in learning English also got good category although there were still two teachers who did not do closing activities because they took too long time in discussing the material.

Learning assessment is carried out based on the assessment standards in the 2013 curriculum by using an authentic approach that assesses students' readiness, process, and 
learning outcomes as a whole. The teachers have prepared the teaching planning and then assessed students' knowledge, social, and attitude by providing rubrics. It is in line with Maba (2017) where the attitude competence assessment consists of spiritual and social attitudes which are gained by observation, self-assessment, peer assessment, and teacher's journal. From the results of analysis, it is known that the attitude assessment by using the peer assessment sheet has a low average. This contrasts with the objective of peer assessment where students are expected to be good learners by actively assisting the teacher in assessing other students as material for consideration and decision making by the teacher.

The results of the study give overview that the ELT K-13 has been well implemented. However, the government through the Ministry of Education and Culture still needs to provide assistance and guidance to teachers in order to improve the quality of their learning. In addition, in the preparation of learning plans and implementation of evaluations, the teachers need to be given intensive guidance so that they can implement the curriculum successfully. In addition, teachers are also expected to be able to increase their understanding of planning stage, implementation and evaluation in the 2013 curriculum.

\section{ACKNOWLEDGEMENTS}

Many thanks to the Ministry of Research and Technology and Higher Education who had funded for this research in 2018 so that this study could be completed on time.

\section{REFERENCES}

Ahmad, D. (2014). Understanding the 2013 Curriculum of English Teaching through the Teachers' and Policymakers' Perspectives. International Journal of Enhanced Research in Education Development (IJERED), 2(4), 6-15.

Ashar, \& Irmawati. (2016). The Implementation of the 2013 Curriculum of English at SMKN 1 Bantaeng : an Evaluative Study. ELT Worldwide, 3(2), 156-170.

Cerbin, W., \& Kopp, B. (2006). Lesson Study as a Model for Building Pedagogical Knowledge and Improving Teaching. International Journal of Teaching and Learning Higher Education, 18(3), 250-257.

Chairani, N. (2015). 2013 Curriculum Reflected in an International Oriented Senior High School, Yogyakarta. Sino-US English Teaching, 12(8), 568-574. https://doi.org/10.17265/1539-8072/2015.08.004

Ediger, M. (2002). Psychological Lesson Plans and Units in Reading. Eric Journal, 4(41), 1-17.

Gunawan, I. (2017). Instructional Management in Indonesia: A Case Study. Journal of Arts, Science \& Commerce, 3(1), 99-107. https://doi.org/DOI: 10.18843/rwjasc/v8i1/12

Handler, B. (2010). Teacher as Curriculum Leader: A Consideration of the Appropriateness of that Role Assignment to Classroom-based Practitioners. International Journal of Teacher Leadership, 3(3), 33-42. 
Hawanti, S. (2014). Implementing Indonesia's English language teaching policy in primary schools: The role of teachers' knowledge and beliefs. International Journal of Pedagogies and Learning, 9(2), 162-170.

Intansari, R. (2013). Teachers' Strategy in Implementing English Curriculum in a Junior High School in Indonesia. Indonesian Journal of Applied Linguistics, 2(2), 226-235.

Maba, W. (2017). Teachers ' Perception on the Implementation of the Assessment Process in 2013 Curriculum. International Journal of Sciences and Humanities, 1(2), 19.

Maba, W., Bagus, I., \& Mantra, N. (2018). The Primary School Teachers' Competence in Implementing the 2013 Curriculum. In SHS Web of C (pp. 1-7). GC Tale.

Muth'im, A. (2014). Understanding and Responding to the Change of Curriculum in the Context of Indonesian Education. American Journal of Educational Research, 2(11), 1094-1099. https://doi.org/10.12691/education-2-11-15

Natsir, Y., Yusuf, Y. Q., \& Nasution, U. F. (2018). The Rise and Fall of Curriculum 2013: Insights on the Attitude Assessment from Practicing Teachers. In SHS Web of Conferences (pp. 1-7). GC Tale.

Nur, M. R., \& Madkur, A. (2014). Teachers' Voices on the 2013 Curriculum for English Instruction Activities. IJEE (Indonesian Journal of English Education), 1(2), 119-134.

Rafique, N., Sultan, B., Ahmad, S., \& Imran, M. (2018). Teachers' Role in Implementation of English Language Teaching Policies in Public Primary Schools of Rural Area in Punjab Pakistan. Language in India, 18(4), 252-261.

Retnawati, H., Hadi, S., \& Nugraha, A. C. (2016). Vocational High School Teachers' Difficulties in Implementing the Assessment in Curriculum 2013 in Yogyakarta Province of Indonesia. International Journal of Instruction, 9(1), 33-48. https://doi.org/10.12973/iji.2016.914a

Rumahlatu, D., Huliselan, E. K., \& Takaria, J. (2016). An Analysis of the Readiness and Implementation of 2013 Curriculum in The West Part of Seram District, Maluku Province, Indonesia. International Journal of Enviromental and Science Education, 11(12), 5662-5675.

Tantra, D. K. (2013). Teaching english as a foreign language in Indonesia: A literature review. Lingual: Journal of Language and Culture, 4(1), 1-7.

Widodo, H. P. (2016). Language Policy in Practice: Reframing the English Language Curriculum. English Language Education Policy in Asia, 1(11), 127-151. https://doi.org/10.1007/978-3-319-22464-0 